\title{
TEH PUTIH (Camellia sinensis) DAN KELOR (Moringa oleifera) SEBAGAI ANTIHIPERGLIKEMIA PADA TIKUS Sprague dawley YANG DIINDUKSI STREPTOZOTOCIN
}

\section{(White tea [Camellia sinensis] and Moringa oleifera as antihyperglycemic agent on streptozotocin-induced diabetic Sprague dawley rats)}

\author{
Amalia Rahma $^{1 *}$, Rina Martini ${ }^{1}$, Clara Meliyanti Kusharto ${ }^{1}$, Evy Damayanthi ${ }^{1}$, \\ Dadan Rohdiana ${ }^{2}$ \\ ${ }^{1}$ Departemen Gizi Masyarakat, Fakultas Ekologi Manusia (FEMA), Institut Pertanian Bogor, Bogor 16680 \\ ${ }^{2}$ Pusat Penelitian Teh dan Kina, Kampung Gambung, Kecamatan Pasir Jambu, Bandung 40972
}

\begin{abstract}
This study aims to examine the antihyperglycemic effect of white tea (Camellia sinensis) and Moringa oleifera when administered as a single component and as mixture in streptozotocin-induced diabetic rats. The study design was experimental. The first step was to analyze epigallocathecingallat (EGCG) content as standard with High Performance Liquid Chromatography (HPLC) method. The second step was intervention in Sprague dawley rats induced by streptozotocin $40 \mathrm{mg} / \mathrm{kgBW}$. Intervention held for 21 days with given white tea (WT), M. oleifera (MO), mixture of white tea and $M$. oleifera $(W T+M O)$ and green tea $(G T)$ as positive control with reference dose $100 \mathrm{mg} / \mathrm{kgBW} E G C G$. Rats blood glucose and body weight were measured. The results are WT having the highest content of EGCG (4.46\%). MO and $W T+M O$ only have $2.42 \%$ and $2.46 \%$ of EGCG while GT as control is the lowest (1.29\%). Measurements of blood glucose and body weight in group that given WT or MO as single component showed no significant difference with control negative group $(p>0.05)$. Blood glucose decreased significantly in group $W T+M O(p<0.05)$. Administration of $W T+M O$ was able to maintain a stable body weight during the intervention period $(p>0.05)$. The combination of white tea and M. oleifera has better ability as an antihiperglycemic agent compared to single component.
\end{abstract}

Keywords: antihiperglycemic, Camellia sinensis, Moringa oleifera, white tea

\begin{abstract}
ABSTRAK
Penelitian ini bertujuan untuk mengkaji efek seduhan teh putih dan kelor jika diberikan sebagai komponen tunggal atau campuran pada tikus hiperglikemia terinduksi streptozotocin (STZ). Desain penelitian adalah eksperimental. Tahap pertama dilakukan analisis kandungan EGCG sebagai standar dengan metode Kromatografi Cair Kinerja Tinggi (KCKT). Tahap kedua intervensi pada tikus Sprague dawley jantan berumur 12 minggu yang telah berhasil diinduksi streptozotocin $40 \mathrm{mg} / \mathrm{kgBB}$ menjadi diabetik. Intervensi dilakukan selama 21 hari dengan menberikan seduhan teh putih (TP), kelor (K), campuran teh putih dan kelor $(\mathrm{TP}+\mathrm{K})$ serta teh hijau $(\mathrm{TH})$ sebagai kontrol positif dengan acuan dosis $100 \mathrm{mg} / \mathrm{kgBB}$ EGCG. Analisis kadar total EGCG diperoleh hasil TP memiliki kadar EGCG terbanyak $(4,46 \%)$. $\mathrm{K}$ dan $\mathrm{TP}+\mathrm{K}$ hanya mengandung $2,42 \%$ dan $2,46 \%$ EGCG. Pengukuran kadar glukosa darah dan berat badan pada kelompok diberi TP atau MO saja menunjukkan hasil yang tidak berbeda nyata dengan $(\mathrm{DM})(\mathrm{p}>0,05)$. Kelompok tikus yang diberi $\mathrm{TP}+\mathrm{K}$ menunjukkan penurunan glukosa darah secara signifikan $(p<0,05)$. Pemberian $\mathrm{TP}+\mathrm{MO}$ mampu mempertahankan berat badan tetap stabil selama masa intervensi $(p>0,05)$. Kombinasi teh putih dan Kelor memiliki kemampuan yang lebih baik sebagai agen antihiperglikemia dibandingkan jika diberikan sebagai komponen tunggal.
\end{abstract}

Kata kunci: antihiperglikemia, Camellia sinensis, kelor, teh putih

\footnotetext{
"Koresponsdensi: Telp: +6285731699450, Surel: rahma.amalia2891@gmail.com
} 
Rahma dkk.

\section{PENDAHULUAN}

Diabetes melitus (DM) merupakan penyakit metabolik yang ditandai dengan hiperglikemia kronis karena gangguan metabolisme karbohidrat, lemak dan protein (Tomás 2013; Indariani et al. 2014). Jumlah penderita diabetes di seluruh dunia pada tahun 2014 sebanyak 422 juta orang dan diperkirakan prevalensinya akan meningkat hingga 592 juta orang pada tahun 2035 (WHO 2016).

Teh merupakan salah satu sumber antioksidan yang mengandung banyak senyawa polifenol terutama epigallocatechin gallat (EGCG) (Abolfathi et al. 2012; Bhattacharya et al. 2013). Kandungan EGCG pada teh diduga mampu berperan sebagai antihiperglikemia melalui mekanisme meningkatkan sensitivitas insulin, melindungi kerusakan sel beta pankreas dari pengaruh oksidasi dan meningkatkan uptake glukosa pada jaringan adiposa (Potenza et al. 2007).

Penelitian pada hewan coba menggunakan teh hijau menunjukkan potensi senyawa aktif teh sebagai antihiperglikemia. Pemberian teh hijau dengan kandungan EGCG $100 \mathrm{mg} / \mathrm{kgBB}$ pada tikus wistar yang diinduksi alloxan selama empat minggu mampu menurunkan glukosa darah 57,9\% (Ramadan et al. 2009). EGCG pada teh hijau juga mampu meningkatkan sensitivitas insulin, melindungi kerusakan sel beta pankreas dari pengaruh oksidasi dan meningkatkan uptake glukosa pada jaringan adiposa. Seduhan teh hijau mampu menekan kerja enzim $\alpha$-glukosidase sebesar 86,7\% (Wei et al. 2010).

Teh putih diklaim memiliki kualitas lebih unggul dibanding jenis teh yang lain karena minimnya proses pembuatan, mengandung antioksidan lebih tinggi dan memiliki sifat antimutagenik (Hilal \& Engelhardt 2007; Teixeira et al. 2012). Berbeda dengan teh hijau, belum banyak penelitian yang dilakukan untuk mengkaji manfaat teh putih terutama pada diabetes melitus.

Selain teh, tanaman perdu lain yang banyak diteliti yang mempunyai efek antihiperglikemia adalah Moringa oleifera atau kelor. Kelor mengandung protein, vitamin, lemak, mineral makro dan mikro, serta senyawa fenol (Farooq et al. 2012). Hasil penelitian Adisakwattana dan Chanathong (2011) dan Soliman (2013) ekstrak daun kelor memiliki aktivitas antihiperglikemia dengan menghambat enzim $\alpha$-glukosidase yang terdapat pada brush border usus halus.

Penelitian ini bertujuan untuk mengkaji pengaruh pemberian tunggal dan campuran seduhan teh putih dan kelor terhadap glukosa darah dan berat badan tikus yang diinduksi streptozotocin (STZ) serta dibandingkan dengan kontrol (teh hijau). Pemberian campuran teh putih dan kelor bertujuan untuk melihat efek sinergistik antara kedua bahan.

\section{METODE}

\section{Desain, tempat, dan waktu}

Desain penelitian ini adalah eksperimental dengan rancangan acak lengkap (RAL). Penelitian dilaksanakan di Laboratorium Balai Pasca Panen dan Unit Pengelola Hewan Laboratorium (UPHL) Fakultas kedokteran hewan (FKH) Institut pertanian Bogor pada pada bulan Januari hingga Juni 2017.

\section{Bahan dan alat}

Bahan utama yang digunakan adalah teh putih dan teh hijau komersial dengan merek dagang "Gamboeng" yang diproduksi oleh Pusat Penelitian Teh dan Kina (PPTK), Bandung dan bubuk kelor komersial dengan merek dagang "Kelorina" yang diproduksi dan diperoleh dari PT Moringa Organik Indonesia, Blora serta tikus Sprague dawley jantan berumur 12 minggu dengan berat 200-300 g sebanyak 24 ekor yang diperoleh dari Indo Animal Lab, Bogor.

Bahan dan alat untuk membuat seduhan teh dan analisis EGCG antara lain aquades, pemanas air, gelas ukur, penyaring, Kromatografi Cair Kinerja Tinggi (KCKT) (Lab Alliance) dilengkapi Rheodyne sample injector $(20 \mu \mathrm{L}$ sample loop), sentrifus, sonikator, kolom fase diam KCKT, vaccum rotary evaporator, vortex, etanol, aseton, etil asetat, heksan, kloroform, diklorometan, etil asetat, etanol, metanol, standar asam tanat, reagen fero sulfat dan kalium natrium tartrat, dinatrium hidrogen pospat, kalium dihidrogen pospat, standar EGCG (Sigma Aldrich), dan seperangkat alat gelas.

Bahan dan alat untuk pemeliharaan hewan coba antara lain kandang, bedding dari serbuk kayu, timbangan digital untuk pengukuran berat badan, botol minum, alat semprot, pakan standar laboratorium. Bahan dan alat untuk induksi hiperglikemia antara lain, streptozotocin (Bioworld $500 \mathrm{mg}$ - 41910012-3), buffer citrat dan spuit injeksi intraperitonial. Bahan dan alat untuk pengecekan glukosa darah antara lain glukometer (Nesco), glucose strip (Nesco), jarum suntik dan alkohol. Berat badan diukur dengan timbangan digital.

\section{Tahapan penelitian}

Persiapan bahan dan pengukuran kadar

EGCG. Tahap pertama penelitian adalah me- 
nentukan kadar EGCG pada seduhan teh hijau, teh putih, kelor, dan campuran teh putih+kelor. Sebanyak 2 g teh putih, kelor, teh putih+kelor dengan perbandingan (50\%:50\%) dan teh hijau diseduh dengan $100 \mathrm{ml}$ air dengan suhu kurang lebih $90^{\circ} \mathrm{C}$ selama lima menit selanjutnya dilakukan penyaringan menggunakan kertas saring. Seduhan teh hijau, teh putih, kelor, dan teh putih+kelor yang telah dibuat sebelumnya diambil sebanyak $50 \mathrm{ml}$ menggunakan pipet dan dimasukkan ke dalam corong pisah ukuran $250 \mathrm{ml}$. Kemudian ditambahkan klorofom $50 \mathrm{ml}$, dikocok selama 2 menit dan dibuang endapan dibagian bawah (diulang tiga kali). Lapisan air diambil untuk diekstraksi dengan etil asetat $50 \mathrm{ml}$ dalam corong pisah $250 \mathrm{ml}$ kemudian dikocok selama dua menit dan dibiarkan hingga terbentuk dua lapisan. Lapisan atas diambil dan lapisan bawah diekstraksi kembali dengan etil asetat dengan volume yang sama (diulang 4 kali). Selanjutnya dilarutkan dengan pelarut pada labu ukur $50 \mathrm{ml}$, diimpitkan, dikocok, disaring dengan Millex $H A$ $0,45 \mu 1$ dan selanjutnya disuntikkan ke KCKT.

Setelah diperoleh hasil analisis EGCG pada tahap pertama penelitian, maka dihitung formulasi seduhan agar didapat konsentrasi pada tiap ml mengandung 12.5-40 mg EGCG supaya seduhan dapat diadministrasikan secara oral (sonde) antara 0.5-2 ml/tikus. Cara yang dilakukan adalah dengan membuat seduhan lebih pekat. Sebanyak $20 \mathrm{~g}$ teh hijau, teh putih, kelor dan campuran teh putih+kelor $(10 \mathrm{~g}$ teh putih $+10 \mathrm{~g}$ kelor) diseduh dengan $200 \mathrm{ml}$ air dengan suhu kurang lebih $90^{\circ} \mathrm{C}$ selama lima menit selanjutnya dilakukan penyaringan menggunakan kertas saring. Filtrat dari hasil penyaringan dipisahkan dari pelarutnya (dikurangi jumlah airnya) menggunakan rotary evaporator dengan suhu $58-60^{\circ} \mathrm{C}$ selama 20 menit (Afify et al. 2011). Pada penelitian ini teh hijau dijadikan sebagai kontrol atau pembanding untuk mengetahui manfaat teh putih, kelor dan campuran teh putih dan kelor karena teh hijau telah banyak diketahui dan dikonsumsi sehari-hari serta telah banyak diteliti sebagai agen antihiperglikemia.

Induksi streptozotocin (STZ) dan pemeliharaan hewan coba. Tikus diadaptasi terlebih dulu selama 14 hari. Selama masa pemeliharaan masing-masing tikus akan diletakkan pada satu kandang. Setelah melewati masa adaptasi, tikus dibagi menjadi kelompok normal sebanyak empat ekor tikus dan kelompok yang diinduksi STZ sebanyak 20 ekor. Tikus diinduksi STZ dengan dosis $40 \mathrm{mg} / \mathrm{kgBB}$ setelah dipuasakan semalam.
Pengukuran pertama dilakukan pada hari ke-3 pasca induksi STZ. Tikus dinyatakan hiperglikemia jika glukosa darah $\geq 126 \mathrm{mg} / \mathrm{dl}$. Jika pada hari ke-3 belum mengalami hiperglikemia maka akan dilakukan pengukuran glukosa darah ulang dua hari berikutnya. Setelah dinyatakan hiperglikemia, 20 ekor tikus akan dibagi menjadi lima kelompok secara acak antara lain kontrol negatif (KN) yaitu yang tidak diberi perlakuan, kontrol positif yaitu yang diberi seduhan teh hijau (TH), kelompok yang diberi teh putih (TH), kelompok yang diberi kelor $(\mathrm{K})$ dan kelompok yang diberi campuran teh putih dan kelor $(\mathrm{TP}+\mathrm{K})$. Intervensi dilakukan selama 21 hari. Kelompok perlakuan diberikan seduhan secara sonde dengan kandungan ECGG $100 \mathrm{mg} / \mathrm{kgBB}$. Penyondean dilakukan pada pukul 09.00-10.00. Semua kelompok diberi pakan standar dan minum secara ad libitum. Pengukuran glukosa darah dengan metode elektrokimia menggunakan glukometer dilakukan setiap tujuh hari sekali. Tikus dipuasakan selama semalam (12-14 jam), kemudian dilakukan pengukuran tikus. Darah diambil dari ekor dengan cara ditusuk menggunakan jarum (prick). Pengukuran glukosa darah puasa dilakukan setiap tujuh hari sekali. Penimbangan berat badan dilakukan setiap tiga hari sekali.

\section{Pengolahan dan analisis data}

Tahapan analisis data glukosa darah puasa dan berat badan antara lain uji normalitas (Shapiro-wilk), paired T-test untuk menguji adanya perbedaan antara sebelum dan sesudah intervensi pada masing-masing variabel, Analisis uji beda antar kelompok menggunakan One-way ANOVA. Jika terdapat perbedaan pengaruh perlakuan yang nyata (signifikan pada $\mathrm{p}<0,05$ ), maka akan dilanjutkan post hoc test least significant difference.

\section{HASIL DAN PEMBAHASAN}

\section{Kandungan EGCG pada Camellia sinensis dan Moringa oleifera}

Epigallocatechin gallat (EGCG) merupakan jenis katekin yang dominan pada teh. Analisis EGCG tersedia pada Tabel 1. Teh putih unggul sebagai jenis teh yang memiliki EGCG terbanyak dibandingkan dengan kelor, kombinasi teh putih dan kelor maupun dengan kontrol (teh hijau).

Kandungan EGCG pada kelor hampir dua kali lipat lebih banyak dibandingkan dengan teh hijau. Kandungan EGCG pada campuran teh putih dan kelor (50\%:50\%) hanya mencapai setengah kali kandungan EGCG pada teh putih namun 
Rahma dkk.

Tabel 1. Analisis kandungan EGCG menggunakan metode Kromatografi Cair Kinerja Tinggi (KCKT)

\begin{tabular}{lc}
\hline \multicolumn{1}{c}{ Kelompok } & EGCG (\%) \\
\hline Teh hijau (TH) & 1,29 \\
Teh putih (TP) & 4,46 \\
Kelor (K) & 2,42 \\
Teh putih + kelor (TP+K) & 2,46 \\
\hline
\end{tabular}

tidak jauh berbeda dengan kandungan EGCG pada kelor. Hasil analisis kandungan EGCG dari campuran $\mathrm{TP}+\mathrm{K}(2.46 \%)$ tidak secara matematis sama dengan jika dihitung dari 50\% EGCG teh putih $+50 \%$ EGCG kelor. Belum diketahui secara pasti penyebab hasil EGCG $(\mathrm{TP}+\mathrm{K})$ tidak sama dengan perhitungan matematisnya, diduga karena adanya interaksi zat aktif antara teh putih dan kelor sehingga EGCG pada tidak dapat terekstrak optimal atau berubah struktur sehingga tidak terdeteksi sebagai EGCG ketika dianalisis.

Penelitian-penelitian serupa yang menganalisis kandungan EGCG, telah banyak dilakukan. Hasil analisis EGCG pada teh hijau dan teh putih sangat beragam. Pengukuran kadar EGCG pada teh hijau antara 0,21\%-9,63\% (Prayong et al. 2007; Martono dan Martono 2012) sedangkan analisis EGCG pada $1 \mathrm{~g}$ teh putih yang diseduh dengan $100 \mathrm{ml}$ air mengandung 2\% (Alves et al. 2015). Senyawa EGCG ekstrak teh putih yang diambil dari perusahaan teh Nanjing Wellchem Enterprise Co. LTDA jauh lebih besar yaitu 19,63\% (Teixeira et al. 2012) sedangkan kandungan EGCG teh putih yang diperoleh dari perkebunan di jerman antara 5,23-9,49\% (Hilal \& Engelhardt 2007). Perbedaan hasil analisis dapat disebabkan oleh varietas dan klon teh, ketinggian tempat, umur daun, jenis petikan, bentuk, tekstur dan proses pengolahan (Kosińska \& Andlauer 2013; Widyaningrum et al. 2015). Penelitian pada teh hijau dari klon berdaun sempit (C. sinensis var. sinensis) menunjukkan epigallocatechin gallate (EGCG) dan epigallocatechin (EGC) yang tinggi, sedang teh hijau dari klon berdaun lebar (C. sinensis var assamica), seperti yang digunakan pada penelitian ini, menunjukkan epicatechin gallate (ECG) dan epicatechin (EC) yang tinggi (Mitrowihardjo 2012).

\section{Perubahan glukosa darah sebelum dan setelah intervensi.}

Pengukuran glukosa darah hari ke-0 (hari pertama mengalami hiperglikemia), menunjukkan terdapat perbedaan yang signifikan glukosa darah kelompok normal dibandingkan dengan kelompok yang diinduksi STZ $(\mathrm{P}<0,05)$. Rata-rata glukosa darah tikus yang diinduksi STZ mencapai 390,53 $\pm 83,9$ sedangkan pada kelompok normal hanya $69,75 \pm 13,47 \mathrm{mg} / \mathrm{dl}$ (Tabel 2).

Berdasarkan uji beda paired t-test antara pengukuran glukosa darah $\mathrm{H}-0$ dan $\mathrm{H}-21$ menunjukkan kelompok KN, TP dan K tidak menunjukkan perubahan glukosa darah puasa yang signifikan $(\mathrm{p}>0,05)$ sedangkan kelompok yang diberi teh hijau (TH) dan campuran teh putih+teh kelor $(\mathrm{TP}+\mathrm{K})$ mengalami penurunan glukosa darah puasa secara signifikan $(\mathrm{p}<0,05)$.

Rata-rata selisih kadar glukosa darah hari ke-0 dan ke-21 ( $\Delta$ glukosa darah) pada kelompok TP menunjukkan kenaikan sebesar 53,3 \pm $86,2 \mathrm{mg} / \mathrm{dL}$ sedangkan kelompok $\mathrm{K}$ dan $\mathrm{TP}+\overline{\mathrm{K}}$ mengalami penurunan sebesar 80,25 $\pm 119,1$ $\mathrm{mg} / \mathrm{dL}$ untuk kelompok $\mathrm{K}$ dan 149,25 $\pm 118,1$ $\mathrm{mg} / \mathrm{dL}$ untuk kelompok TP+K. Berdasarkan uji ANOVA terhadap $\Delta$ glukosa darah menunjukkan kelompok TP dan K tidak menunjukkan perbedaan yang signifikan dengan kelompok $\Delta$ glukosa darah tikus yang diinduksi STZ tanpa perlakuan $(\mathrm{KN})(\mathrm{p}>0,05)$ namun berbeda nyata dengan kelompok TH $(\mathrm{p}<0,05)$. Berbeda dengan kelompok $\mathrm{TP}$ dan $\mathrm{K}$, kelompok $\mathrm{TP}+\mathrm{K}$ mengalami penurunan glukosa darah yang berbeda signifikan

Tabel 2. Kadar glukosa darah sebelum dan sesudah diintervensi

\begin{tabular}{|c|c|c|c|c|}
\hline \multirow{2}{*}{ Kelompok } & \multicolumn{2}{|c|}{ Rata-rata+ sd (mg/dl) } & \multirow{2}{*}{$\begin{array}{l}\text { Rata-rata } \Delta \mathrm{GDP} \pm \mathrm{sd} \\
(\mathrm{mg} / \mathrm{dl})\end{array}$} & \multirow[b]{2}{*}{$p$} \\
\hline & Sebelum intervensi $(\mathrm{H}-0)$ & Sesudah intervensi $(\mathrm{H}-21)$ & & \\
\hline KN & $420,25 \pm 66,77^{\mathrm{bc}}$ & $444,25 \pm 78,7^{\mathrm{c}}$ & $-24,0 \pm 61,62^{\mathrm{a}}$ & 0,518 \\
\hline $\mathrm{TH}$ & $294,35 \pm 35,02^{\mathrm{a}}$ & $149,25 \pm 57,07^{\mathrm{a}}$ & $145 \pm 59,8^{b}$ & $0,017 *$ \\
\hline TP & $345,00 \pm 75,5^{\mathrm{ab}}$ & $398,33 \pm 14,2^{\mathrm{c}}$ & $-53,3 \pm 86,2^{a}$ & 0,396 \\
\hline $\mathrm{K}$ & $460,25 \pm 61,31^{\mathrm{c}}$ & $380 \pm \overline{7} 6,23^{c}$ & $80,25 \pm 119,1^{\mathrm{ab}}$ & 0,271 \\
\hline $\mathrm{TP}+\mathrm{K}$ & $421,5+74,99^{\mathrm{bc}}$ & $272,2 \overline{5}+77,89^{b}$ & $149,25+118,1^{b}$ & $0,031 *$ \\
\hline $\begin{array}{l}\text { Normal } \\
\mathrm{p}\end{array}$ & $69,75 \pm 13,47^{\mathrm{d}}$ & $79 \pm 10,23^{d}$ & $\begin{array}{c}-3,5 \pm 12,4^{b} \\
0,014 * *\end{array}$ & 0,612 \\
\hline
\end{tabular}

*) Paired t-test, signifikan pada $\mathrm{p}<0,05$.

**) Anova dilanjutkan post hoc Least Significant Different, signifikan pada $\mathrm{p}<0,05$, perbedaan abjad menunjukkan berbeda nyata. 
dengan kelompok $\mathrm{KN}(\mathrm{p}<0,05)$ dan tidak berbeda nyata dengan kelompok $\mathrm{TH}$.

STZ merupakan senyawa diabetogenik yang dapat secara langsung merusak masa kritis sel beta langerhans atau menimbulkan proses autoimun terhadap sel beta. STZ memiliki sifat toksik dikarenakan adanya aktivitas alkilasi dari gugus metilnitrosourea terutama pada posisi $\mathrm{O}^{6}$ dari guanin. Tranfer gugus metil dari STZ ke molekul DNA menyebabkan kerusakan pada sepanjang rantai yang mengalami alkilasi, yang selanjutnya menyebabkan fragmentasi DNA. Kerusakan ini menyebabkan penurunan $\mathrm{NAD}^{+}$dan ATP seluler sehingga sel beta mengalami nekrosis dan menurunnya produksi insulin (Nugroho 2006). Masuknya STZ melalui GLUT2 juga menyebabkan menurunnya ekspresi GLUT2. GLUT2 mempunyai sifat mengangkut glukosa ke dalam sel tanpa batas. Hal ini mengakibatkan menurunnya sensitifitas reseptor insulin perifer sehingga berdampak pada meningkatnya resistensi insulin dan meningkatkan kadar glukosa darah (Firdaus et al. 2016).

Epigallocatechin gallat (EGCG) yang terkandung dalam teh hijau, teh putih dan kelor mampu menghambat terjadinya glukoneogenesis melalui penghambatan sintesis fosfoenolpiruvat karboksikinase di hati (Chemler et al. 2007). Fosfoenolpiruvat karboksikinase merupakan enzim yang berperan sebagai katalis tahapan glukoneogenesis. Hasil penelitian menunjukkan bahwa transkripsi enzim fosfoenolpiruvat karboksikinase menurun dalam beberapa menit setelah injeksi insulin (Chakravarty \& Hanson 2007). Hal ini mungkin yang menyebabkan EGCG dianggap memiliki sifat yang menyerupai insulin (insulinlike). EGCG juga dapat meregenerasi sel beta pancreas serta menstimulasi pembentukan dan aktivitas insulin (Chemler et al. 2007).

Teh hijau, teh putih dan kelor juga mengandung senyawa flavonol (kuersetin dan kaemferol) (Gondoin et al. 2010; Zhang et al. 2011) yang berperan sebagai inhibitor enzim $\alpha$-amilase dan $\alpha$-glukosidase (Wei et al. 2010; Adisakwattana dan Chanathong 2011). Inhibisi kerja enzim tersebut mampu mengurangi pencernaan karbohidrat sehingga dapat mengurangi peningkatan kadar glukosa darah postprandial (Shinde et al. 2008). Kandungan kuersetin dan kaemferol pada teh hijau lebih banyak dibandingkan teh putih (Gondoin et al. 2010) sedangkan kuersetin pada kelor tersari lebih baik jika diekstrak dengan etanol dibandingkan dengan air (Sulistiawati \& Pratiwi 2015). Hal ini diduga yang menyebabkan penurunan glukosa darah teh hijau lebih baik dibandingkan dengan teh putih atau kelor namun apabila teh putih dikombinasikan dengan kelor terjadi penurunan glukosa yang tidak berbeda dengan teh hijau. Hal ini diduga adanya efek sinergistik antara komponen aktif pada kedua bahan seperti EGCG dan kuersetin.

Kandungan kafein pada teh putih yang lebih banyak dibandingkan dengan teh hijau dan kelor (Hilal \& Engelhardt 2007; Dias et al. 2013) diduga menyebabkan kenaikan glukosa darah pada kelompok TP. Kafein merangsang pelepasan hormon epinefrin dan norepinefrin yang dapat menyebabkan peningkatan glukoneogenesis hepatik, glikogenolisis hepatik dan otot (Nunes et al. 2015). Konsumsi kafein dalam jumlah sedang mampu memberikan perlindungan pada persarafan, menurunkan resistensi dan disfungsi insulin (Duarte et al. 2009). Campuran teh putih dan kelor, yang hanya terdiri dari $50 \%$ teh putih, menunjukkan penurunan glukosa darah lebih baik dan tidak berbeda nyata dengan kontrol positif (TH).

\section{Perubahan berat badan sebelum dan sesudah intervensi.}

Penurunan berat badan umum terjadi pada penderita diabetes karena meningkatnya glukoneogenesis dan menurunnya glikogenesis. Hal tersebut juga terjadi pada hewan coba yang diin-

Tabel 3. Perubahan berat badan sebelum dan setelah intervensi

\begin{tabular}{|c|c|c|c|c|}
\hline \multirow{2}{*}{ Kelompok } & \multicolumn{2}{|c|}{ Rata-rata \pm sd $(\mathrm{g})$} & \multirow{2}{*}{ Rata-rata $\Delta$ berat badan $\pm \mathrm{sd}(\mathrm{g})$} & \multirow[b]{2}{*}{$p$} \\
\hline & Sebelum intervensi & Sesudah intervensi & & \\
\hline $\mathrm{KN}$ & $252,5 \pm 25,37$ & $212,75 \pm 21,06^{\mathrm{ab}}$ & $39,75 \pm 10,37^{\mathrm{bc}}$ & $0,005^{*}$ \\
\hline $\mathrm{TH}$ & $279,5 \pm 24,83$ & $259,75 \pm 25,38^{c}$ & $19,75+17,27^{\mathrm{c}}$ & 0,106 \\
\hline $\mathrm{TP}$ & $245 \pm 30,43$ & $183,25 \pm 27,95^{\mathrm{a}}$ & $61,75 \pm 16,7^{\mathrm{ab}}$ & $0,005^{*}$ \\
\hline K & $259,3 \overline{3} \pm 33,34$ & $185,75 \pm 10,5^{\mathrm{a}}$ & $73,25 \pm 29,8^{a}$ & $0,016^{*}$ \\
\hline $\mathrm{TP}+\mathrm{K}$ & $266,25 \pm 17,58$ & $243,25+28,98^{\mathrm{bc}}$ & $23 \pm \overline{33}, 45^{\mathrm{c}}$ & 0,263 \\
\hline $\begin{array}{l}\text { Normal } \\
\mathrm{p}\end{array}$ & $276 \pm 16,18$ & $308,5 \pm 18,19^{\mathrm{d}}$ & $\begin{array}{c}-32,5 \pm 5,1^{\mathrm{d}} \\
0.000^{*}\end{array}$ & $0,001 *$ \\
\hline
\end{tabular}

*) Paired t-test, signifikan pada $\mathrm{p}<0,05$.

**) Anova dilanjutkan post hoc Least Significant Different, signifikan pada $\mathrm{p}<0.05$, perbedaan abjad menunjukkan berbeda nyata. 
duksi dengan streptozotocin. Penimbangan awal intervensi, tikus memiliki berat badan rata-rata $263,04 \pm 27,64 \mathrm{~g}$ dan tidak ada perbedaan yang signifikan berat badan antar kelompok (Tabel 3).

Hasil uji beda paired t-test antara pengukuran $\mathrm{H}-0$ dan $\mathrm{H}-21$ menunjukkan kelompok $\mathrm{KN}$, TP dan $\mathrm{K}$ mengalami penurunan berat badan secara signifikan sedangkan tikus yang diberi teh hijau (TH) dan kombinasi teh putih+teh kelor $(\mathrm{TP}+\mathrm{K})$ mampu mempertahankan berat badan tetap stabil $(\mathrm{p}>0,05)$ (Tabel 3). Selisih berat badan H-0 dan H-21 ( $\Delta$ berat badan) pada kelompok TP dan K mengalami penurunan berat badan terbanyak yaitu masing-masing 61,75 \pm $16,7 \mathrm{~g}$ dan $73,25 \pm 29,8 \mathrm{~g}$ sedangkan pada kelompok $\mathrm{TP}+\mathrm{K}$ mengalami penurunan berat badan sebesar $23 \pm 33,45$ g. Berdasarkan uji ANOVA $\Delta$ berat badan menunjukkan $\Delta$ berat badan kelompok $\mathrm{K}$ berbeda signifikan dengan kelompok $\mathrm{KN}$ $(\mathrm{p}<0,05)$ sedangkan kelompok TP dan $\mathrm{TP}+\mathrm{K}$ tidak berbeda signifikan dengan $\mathrm{KN}(\mathrm{p}>0,05)$. Jika dibandingkan dengan kelompok kontrol positif (TH), $\Delta$ berat badan kelompok TP dan K berbeda signifikan dengan kelompok TH $(\mathrm{p}<0,05)$, dan $\Delta$ berat badan kelompok $\mathrm{TP}+\mathrm{K}$ tidak berbeda signifikan dengan kelompok $\mathrm{TH}(\mathrm{p}<0,05)$.

Hubungan berat badan dan glukosa darah terkait dengan adanya gangguan dari penyediaan dan pemanfaatan glukosa sebagai sumber energi. Penelitian Habibuddin et al (2008); Zafar dan Naqfi (2010) dan Nagarchi et al. (2015) menjelaskan semakin meningkatnya glukosa darah maka semakin menurun berat badan. Penderita diabetes mellitus tidak dapat memperoleh energi dari katabolisme glukosa sehingga tubuh akan mencari alternatif substrat untuk menghasilkan energi.

Glukosa yang tidak tersedia di dalam sel mengakibatkan terjadinya glukoneogenesis secara berlebihan. Sel-sel hati akan meningkatkan produksi glukosa dari substrat lain yaitu protein dan lemak. Kejadian tersebut berlangsung terus menerus karena insulin yang membatasi glukoneogenesis sangat sedikit atau tidak ada sama sekali. Glikogenesis pun akan terhambat karena enzim yang berperan dalam jalur tersebut diinaktivasi tanpa kehadiran insulin. Glukosa yang dihasilkan kemudian akan terbuang melalui urine dan mengakibatkan degenerasi jaringan otot dan jaringan adiposa secara signifikan (Ene et al. 2007; Umami et al. 2015).

Shokri et al. (2015) mengemukakan bahwa tikus yang diintervensi dengan ekstrak teh hijau sebanyak 100 dan $200 \mathrm{mg} / \mathrm{kgBB}$ mampu mempertahankan berat badan dengan lebih stabil dan berbeda signifikan dengan kelompok kontrol negatif (DM). Jika diberikan teh hijau dalam do- sis yang lebih kecil (50 mg/kgBB) tidak menunjukkan hasil yang signifikan jika dibandingkan dengan kelompok DM.

Konsumsi teh terbukti mampu meningkatkan pembentukan glikogen di hati dengan mereaktifkan glikogen sintetase. Kandungan EGCG yang terkandung dalam teh mampu menghambat terjadinya glukoneogenesis melalui penghambatan sintesis fosfoenolpiruvat karboksikinase di hati. Fosfoenolpiruvat karboksikinase merupakan enzim yang berperan sebagai katalis tahapan glukoneogenesis (Chemler et al. 2007).

Berbanding terbalik dengan kemampuannya mempertahankan berat badan, EGCG pada teh dapat meningkatkan termogenesis dan mengeluarkan energi sebanyak 4\% sepanjang 24 jam, mampu meningkat oksidasi lemak dan menghambat aktivitas Catechol-O-metyltransferase memperpanjang stimulasi termogenesis. Katekin mampu menghambat absorbsi lemak dan menekan sintesis asam lemak dengan menghambat enzim asetil KoA karboksilase (Shokri et al. 2015).

Kadar kafein mampu meningkatkan hormon epinefrin dan norepinefrin yang menyebabkan katabolisme dari glikogen, protein dan lemak pada hati dan otot untuk diubah menjadi glukosa sehingga berat badan pun ikut menurun drastis (Sepkowitz 2013). Hal tersebut diduga yang menyebabkan tikus yang diinduksi STZ dan diberi teh tetap mengalami penurunan serta tidak dapat menyamai perubahan berat tikus nomal

\section{KESIMPULAN}

Pemberian teh putih (TP) atau kelor (K) secara tunggal selama 21 hari belum mampu menurunkan glukosa darah secara signifikan sedangkan kelompok yang diberi teh putih+teh kelor $(\mathrm{TP}+\mathrm{K})$ dengan perbandingan 50\%:50\% mampu menurunkan glukosa darah puasa secara signifikan. Penurunan glukosa darah kelompok $\mathrm{TP}+\mathrm{K}$ berbeda signifikan dengan kelompok KN namun tidak berbeda signifikan dengan kelompok TH. Kelompok TP dan K juga mengalami penurunan berat badan secara signifikan sedangkan kelompok $\mathrm{TP}+\mathrm{K}$ mampu mencegah berat badan menurun secara signifikan. Penurunan berat badan kelompok $\mathrm{TP}+\mathrm{K}$ berbeda signifikan dengan kelompok KN tetapi tidak berbeda nyata dengan kelompok teh hijau (TH).

Kandungan EGCG diduga bukan satusatunya komponen yang berpengaruh terhadap glukosa darah dan berat badan sehingga disarankan untuk menganalisis komponen lain seperti kafein, kuersetin, kaemferol dan senyawa 
flavonoid lainnya. Penelitian lebih lanjut dalam menentukan persentase campuran teh putih dan kelor perlu dilakukan untuk mendapatkan rasio optimal yang memberikan hasil terbaik secara manfaat dan ekonomi.

\section{DAFTAR PUSTAKA}

Abolfathi AA, Mohajeri D, Rezaie A, Nazeri M. 2012. Protective effects of green tea extract against hepatic tissue injury in streptozotocin-induced diabetic rats. eCAM. 2012(1):1-10.

Adisakwattana S, Chanathong B. 2011. Alphaglucosidase inhibitory activity and lipidlowering mechanisms of Moringa oleifera leaf extract. Eur Rev Med Pharmacol Sci. 15(7):803-808.

Afify AEMR, shalaby EA, El-Beltagi HS. 2011. Antioxidant Activity of Aqueous Extracts of Different Caffeine Products. Not Bot Horti Agrobo. 39(2):117-123.

Alves MG, Martins AD, Teixeira NF, Rato L, Oliveira PF, Silva BM. 2015. White tea consumption improves cardiac glycolytic and oxidative profile of prediabetic rats. J Funct Foods. 14(1):102-110.

Bhattacharya S, Manna P, Gachhui R, Sil PC. 2013. D-saccharic acid 1,4-lactone protects diabetic rat kidney by ameliorating hyperglycemiamediated oxidative stress and renal inflammatory cytokines via NF$\kappa \mathrm{B}$ and PKC signaling. Toxicol Appl Pharmacol. 267(1):16-29.

Chakravarty K, Hanson RW. 2007. Insulin regulation of phosphoenolpyruvate carboxykinase-c gene transcription: the role of sterol regulatory element-binding protein 1c. Nutr Rev. 65(1):S47-S56.

Chemler JA, Lock LT, Koffas MA. 2007. Standardized biosynthesis of flavan-3-ols with effects on pancreatic b-cell insulin secretion. Appl Microbiol Biotechnol. 77(4):797-807.

Dias TR, Tomás G, Teixeira NF, Alves MG, Oliveira PF, Silva BM. 2013. White tea (Camellia sinensis): antioxidant properties and beneficial health effects. Int J Food Sci. 2(2):19-26.

Duarte JM, Carvalho RA, Cunha RA, Gruetter R. 2009. Caffeine consumption attenuates neurochemical modifications in the hippocampus of streptozotocin-induced diabetic rats. J Neurochem. 111(2):368-379.

Ene AC, Nwankwo EA, Samdi LM. 2007. Alloxan-induced diabetes in rats and the effects of black caraway (Carum carvi L.) oil on their body weight. Res J Med Sci. 2(2):4852.

Farooq F, Rai M, Tiwari A, Khan AA, Farooq S. 2012. Medicinal properties of Moringa oleifera: an overview of promising healer. J Med Plants Res. 6(27):4368-4374.

Firdaus, Rimbawan, Marliyati SA, Roosita K. 2016. Model tikus diabetes yang diinduksi streptozotocin sukrosa untuk pendekatan penelitian diabetes melitus gestasional. MKMI. 12(1):29-34.

Gondoin A, Grussu D, Stewart D, McDougall GJ. 2010. White and green tea polyphenols inhibit pancreatic lipase in vitro. Food Res Int. 43(5): 1537-1544.

Habibuddin M, Daghriri HA, Humaira T, Al-Qahtani MS, Hefzi AA. 2008. Antidiabetic effect of alcoholic extractof Caralluma sinaica L. on streptozotocin-induced diabetic rabbits. J Ethnopharmacol. 117(2):215220.

Hilal, Engelhardt. 2007. Characterisation of white tea-comparison to green and black tea. J Verbrauch Lebensm. 2(4):414-421.

Indariani $\mathrm{S}$, Wijaya $\mathrm{CH}$, Rahminiwati $\mathrm{M}$, Winarno, MW. 2014. Antihyperglycemic activity of functional drinks based on Java Tea (Orthosiphon aristatus) in streptozotocin induced diabetic mice. Int Food Res J. 21(1):349-355.

Kosińska A, Andlauer W. 2013. Antioxidant capacity of tea: effect of processing and storage. Processing and Impact on Antioxidants in Beverages. Cap 12:109-109.

Martono Y, Martono S. 2012. Analisis kromatografi cair kinerja tinggi untuk penetapan kadar asam galat, kafein dan epigalokatekin galat pada beberapa produk teh celup. AGRITECH. 32(4):362-369.

Mitrowihardjo S. 2012. Kandungan katekin dan hasil pucuk beberapa klon teh (Camelia sinensis (L.) O. Kuntze) unggulan pada ketinggian yang berbeda di kebun Pagilaran. [Disertasi]. Program Studi Pemuliaan Tanaman. Fakultas Pertanian UGM. Yogyakarta.

Nagarchi K, Ahmed S, Sabus A, Saheb SH. 2015. Effect of streptozotocin on glucose levels in albino wistar rats. Int J Pharm Sci Res. 7(2):67-69.

Nugroho AE. 2006. Hewan percobaan diabetes mellitus: patologi dan mekanisme aksi diabetogenik. BIODIVERSITAS. 7(4):378382. 
Rahma dkk.

Nunes AR, Alves MG, Tomás GD, Conde VR, Cristóvão AC, Moreira PI, Oliveira PF, Silva BM. 2015. Daily consumption of white tea (Camellia sinensis (L.)) improves the cerebral cortex metabolic and oxidative profile in prediabetic Wistar rats. Br J Nutr. 113(5):832-842.

Potenza MA, Marasciulo FL, Tarquino M, Tiravanti E, Colantuono G Federici A, Kim JA, Quon MJ, Montagnani M. 2007. EGCG, a green tea polyphenol, improves endothelial function and insulin sensitivity, reduces blood pressure, and protects against myocardial I/R injury in SHR. Am J Physiol Endocrinol Metab. 292(5):E1378-E1387.

Prayong P, Weerapreeyakula N, Sripanidkulchaia B. 2007. Validation of isocratic eluting and stepwise flow rate gradient for hplc determination of catechins, gallic acid and caffeine in tea. SCIENCEASIA. 33:113-117.

Ramadan G, El-Beih NM, Abd EA. 2009. Modulatory effects of black $v$. green tea aqueous extract on hyperglycaemia, hyperlipidaemia and liver dysfunction in diabetic and obese rat models. Br J Nutr. 102(11):16111619.

Sepkowitz KA. 2013. Energy drinks and caffeine-related adverse effects. JAMA. 309(3):243-244.

Shinde J, Taldone T, Barletta M, Kunaparaju N, Bo H, Kumar K. 2008. Alpha-glucosidase inhibitory activity of Syzygium cumini (Linn) skeels seed kernel in vitro an in Goto-Kakizaki (GK) rats. Carbohydr Res. 343(7):1278-1281.

Shokri G, Fathi H, Sabet MJ, Nasrabadi NN, Ataee R. 2015. Evaluation of anti-diabetic effects of hydroalcoholic extract of green tea and cinnamon on streptozotocin-induced diabetic rats. J Pharm Biomed Anal. $1(2): 20-29$.

Soliman GZA. 2013. Anti-diabetic activity of dried moringa oleifera leaves in normal and streptozotocin (STZ)-induced diabetic male rats. Indian J Appl Res. 3(9):18-23.
Sulistiawati R, Pratiwi PY. 2016. Pengaruh pemberian ekstrak etanol daun kelor (Moringa oleifera 1.) terhadap aktivitas analgesik dan antiinflamasi melalui ekspresi enzim siklooksigenase. Pharmaciana. 6(1):31-38.

Teixeira GL, Lages PC, Jascolka TL, Aguilar EC, Soares FLP, Pereira SS, Beltrao NRM, Nascimento A, Castillo RO, Leite J. 2012. White Tea (Camellia sinensis) extract reduces oxidative stress and triacylglicerols in obese mice. Ciencia e Technologia de Alimentos. 32(4):733-741.

Tomás G. 2013. Male fertility and type 2 diabetes mellitus: effect of white Tea. [Disertasi]. Portugal: Biomedical Sciences University of Beira Interior.

Umami Z, Nurdiana, Nugroho FA. 2015. Efek pemberian susu sapi bubuk terhadap kadar serum hdl (high density lipoprotein) pada tikus putih (Rattus norvegicus) galur wistar model diabetes melitus tipe 2. J Gizi Pangan. 10(1):1-8.

Wei X, Zhiwei Y, Yanhong G, Jianbo X, dan Yuanfeng W. 2010. Composition and Biological Activity of Tea Polysaccharides Obtained by Water Extraction and Enzymatic Extraction. LAT AM J PHARM. 29 (1): 117-121.

Widyaningrum N, Fudholi A, Sudarsono, Setyowati EP. 2015. Stability of epigallocatechin gallate (EGCG) from green tea (Camellia sinensis) and its antibacterial activity against Staphylococcus epidermidis ATCC 35984 and Propionibacterium acnes ATCC 6919. Asian J Biol Life Sci. 8(2): 93-101.

[WHO] World Health Organization. 2016. Global report on diabetes. WHO Library Cataloguing-in-Publication Data.

Zafar M, Naqfi SNH. 2010. Effects of stz-induced diabetes on the relative weights of kidney, liver and pancreas in albino rats: a comparative study. Int J Morphol. 28(1):135-142.

Zhang M, Swarts SG, Yin L, Liu C, Tian Y, Cao Y. 2011. Antioxidant properties of quercetin. Adv Exp Med Biol. 701(2): 283-289. 